\title{
Determinants of Bank Selection: A Study of Undergraduate Students in the University of Ghana
}

\author{
Robert E. Hinson", Aihie Osarenkhoe ${ }^{2}$, Abednego Feehi Okoe ${ }^{3}$ \\ ${ }^{1}$ University of Ghana Business School, Legon-Accra, Ghana; ${ }^{2}$ Department of Business \& Economic Studies, Faculty of Education \& \\ Economics, University of Gävle, Gävle, Sweden; ${ }^{3}$ University of Professional Studies, Legon-Accra, Ghana. \\ Email: aoh@hig.se
}

Received December $10^{\text {th }}, 2012$; revised January $15^{\text {th }}, 2013$; accepted March 20 $0^{\text {th }}, 2013$

Copyright (c) 2013 Robert E. Hinson et al. This is an open access article distributed under the Creative Commons Attribution License, which permits unrestricted use, distribution, and reproduction in any medium, provided the original work is properly cited.

\begin{abstract}
The aim of this study is twofold: first, to investigate bank selection criteria among undergraduate students in the University of Ghana, and second, to relate this study with previous findings on the same phenomenon. Extant studies have adopted mainly quantitative approach. In order to bridge this gap and contribute to existing knowledge, qualitatively inspired research design was adopted, thus facilitating in-depth understanding of the determinants of bank selection. Findings show that convenience, bank staff-customer relations and banking services/financial benefits are the first three most important determining factors. Furthermore, happiness, joyfulness, cheerfulness and delight are feelings derived after a banking service; whiles sadness, anger and deceit are avoided. Studies on the bank selection criteria employed by undergraduates are scanty in West Africa, and this study makes a contribution in that direction. Future studies will continue from this one.
\end{abstract}

Keywords: Bank Industry; Selection Criteria; Decision Hierarchy Model; University of Ghana

\section{Introduction}

Many companies in real business currently conform to service trends by shifting their business from goods to services [1]. With growing competitiveness in the banking industry [2,3], and similarity of services offered by banks [4], it has become increasingly important that banks identify the factors that determine the basis upon which customers choose between providers of financial services. Against this background, extant literature has addressed the issue of how customers select banks [3-8]. Exploring such information will help banks to identify the appropriate marketing strategies needed to attract new customers and retain existing ones [9]. Consequently, the relevant literature indicates that a great deal of research effort has been expended to investigate bank selection criteria for broad categories of customers [10].

Competition in the Banking industry has become fierce [2]. In Ghana this competition has intensified due to a number of factors. Chief among them is the passage of the universal banking law as reported by [11]. They observe that all types of banking can be conducted under a single corporate banking entity and this has greatly reorganized the competitive scopes of several banking prod- ucts in Ghana. Prior to the 1990's however, banks operated in a highly regulated and a non competitive environment in Ghana [12]. Also the influx of international banks (especially Nigerian Banks) onto the Ghanaian Banking scene over the last decade implies that the boundary of competition among banks in Ghana has further been extended. The number of commercial banks licensed to operate in Ghana increased from 16 with 277 branches (Ghana Review International report, 1999) in 1998 to 27 by June 2009 [4]. Hinson et al. note that an ever increasing branch network of over 600 branches for the 25 banks, the Ghanaian banking sector is a very competitive sector within which to operate [13].

The emergence of technology (telecommunications, ATM, mobile banking, electronic banking, credit cards, home banking) is another factor that is quickly changing the face of competition in the banking industry in the world [14,15]. Some scholars are of the view that the future determinant of competition in the banking industry in the world would be technology. Consumers have become more sophisticated in their demand for financial services [14]. How students choose banks they patronize has been given considerable attention in scholarly litera- 
ture [13,16-23]. This has become necessary because students are seen as a large segment that meets the requirements for a successful implementation of market segmentation strategies. Lewis, in his work entitled "Student accounts - a profitable segment notes how profitable the student market segment has become [22]. Banks which are planning to cultivate this vibrant market segment must understand how individuals belonging to such a segment select their banks.

The empirical data collection for this study draws on a case encompassing one empirical context—undergraduate students. We choose the undergraduate students because of the following reasons: The general student population in Ghana has constantly been growing for the last decade. This is evidence by the upsurge in the number of private universities throughout Ghana. There has been an expansion in the program offerings of some of these universities. Institute of Professional Studies (IPS) for instance is now offering degree courses in addition to the professional courses they are noted for. The current student population of University of Ghana is 29,754. www.ug.edu.gh. The sheer size of the student population on the University of Ghana Campus makes it ideal for segmentation. Secondly Students who do not have bank accounts would need one because students' loans and bursaries are disbursed directly through student's bank accounts [24]. Remittances from guardians can conveniently be received through one's bank account also. Finally, those who are still studying and do not have bank accounts, will have one when they complete their education and start to work because almost all companies in Ghana pay salaries directly through employees bank accounts. In the wake of the intense competition in the Ghanaian Banking industry, banks in Ghana are beginning to see the student market as a huge prospect. A casual observation on the university of Ghana campus reveals a rise in the number of bank branches. HFC Bank, Ecobank and Cal Bank have joined the three existing banks (Barclays Bank, Standard Chartered Bank and Ghana Commercial Bank). ATM services have also been provided by Cal Bank Limited, Ecobank, International Bank Limited; and several others.

Despite the importance of student bank market segment, literature on which factors students consider in selecting a bank in West Africa in general and Ghana in particular is very scanty. As revealed by the literature, bulk of the studies on the criteria that students use in selecting a bank has North America, Europe and Asia origins. Out of the few scholars, Owusu-Frimpong, Hinson et al. and Blankson et al. appear to be the only researched work on the factors that determined bank selection among undergraduates in Ghana [12,13,16]. Even in the case of Blankson et al., their work was cross-national [16]. This paper aims to investigate bank selection crite- ria among undergraduate students in the University of Ghana. This study differs from previous studies because it will investigate how undergraduate students in the University of Ghana select a bank. We will find out to what extent our findings are in agreement with other studies.

\section{Literature Review}

Pioneer researchers on the selection criteria employed by students in selecting a bank [22,23] establish that convenience and parental influence are the most important factors influencing students' bank selection [24]. This position was later corroborated by Schram in his article about American college students [21]. However, Zineldin's study challenged previous findings on the importance of a close bank or branch to a customer home or work [15]. He attributes his position to the emergence of today's telecommunication, ATM, home banking, credit cards and mobile banking. An important dimension was, however, given to the convenience variable by [25]. They argue that although convenience is one of the most important criteria for bank selection, definition of convenience vary across consumers. This view is consistent with the findings of Blankson et al. They note the overlap in competence and convenience. And that "convenience" is a latent factor embedded with "competence" [16].

Tan and Chua [26], on the other hand, strongly support the third party argument by Gray [23] and Lewis [22], disagree with convenient location criterion. The findings sharply contrast Tan and Chua [26], Gray [23] and Lewis, in that their study of Singaporean graduate students reveals that family and friends influence is not so important [22]. Most of these research findings, despite their inconsistencies or significant differences appear to overlap in one way or the other [27]. For example, both Zineldin [15] and Anderson et al. [28] strongly agree that banks reputation, credit availability and charges are sensitive for customers. However peer recommendation was not so important in Zineldin's work, whereas it emerges as a very important factor in Anderson et al. [28]. Another study which focuses on factors that influence the selection of banks in New Zealand shows that fast and efficient service, friendly and helpful staff and the reputation of the bank are very important factors [20].

In West Africa, Owusu-Frimpong's study shows that Ghanaian consumers value efficient services, favourable interest rates on savings accounts, influence from peers are very important in deciding which bank to patronize [12]. Another study shows that Nigerians value time highly and as such would prefer fast and quality services [29]. In contrast to Tan and Chua's work [26], Hinson et al. study reveals that bank customers view proximity/ accessibility as the most important factor in the opening 
and maintenance of accounts with banks in Ghana whereas peer recommendations appear not so important [13]. However, their finding on convenience is in agreement with that of Blankson et al. [16]. However, the role of word of mouth [12] as an effective tool to communicate banks services is not supported by Hinson et al. [13]. The work done on the determinants of banks selection in USA, Taiwan and Ghana shows that convenience, competence, and no bank charges were consistent in all the three countries surveyed [16]. The competence and quality service factors are evident in Omar's work [29]. Convenience and proximity are mentioned as important determinants of bank selection in other studies $[13,29]$. Finally, other findings corroborate "no charges" [12], sensitive to price and sensitivity to high rate of interest [29] as important determinants.

\section{Theoretical Framework}

Decision hierarchy model for the selection of banks developed by Ta \& Har [19] was adopted. The decision hierarchy for the selection of bank is based on nine criteria for deciding on a bank. The model presents three elements; respondents to make a decision, the nine criteria that influence decision and the decision alternatives (i.e. banks in Ghana). The first component of the model requires respondents to make a decision to select a bank. The second element presents the nine criteria with which respondents use in selecting a bank, in other words the determinants of bank selection. The final component is the banks in Ghana which the respondents are to choose influenced by the nine criteria. Our goal is to find out whether these criteria are the same used by undergraduate students in Ghana or otherwise. The model gives us a framework why undergraduates select a bank. Thus will serve as the basis for analyzing the reasons why undergraduates select a particular bank over the other. This is illustrated in Figure 1 below.

\section{Methodology}

The main aim of this study is to investigate bank selection criteria among undergraduate students in the University of Ghana, and second, to relate this study with previous findings on the same phenomenon. The empirical data collection draws on a case encompassing one empirical context-undergraduate students. We choose the undergraduate students because of the reasons outlined earlier in the introduction section of this paper. We employ qualitative techniques which, according to Yin, are to provide insights and not to measure [30]. Furthermore, a qualitative research approach was chosen because only qualitative research methods were believed to be the most appropriate to allow the detailed analysis of complex case in point and this allowed the researcher to penetrate their realities and uncover issues of relevance in understanding the substantive research question: What are the determinants of bank selection?

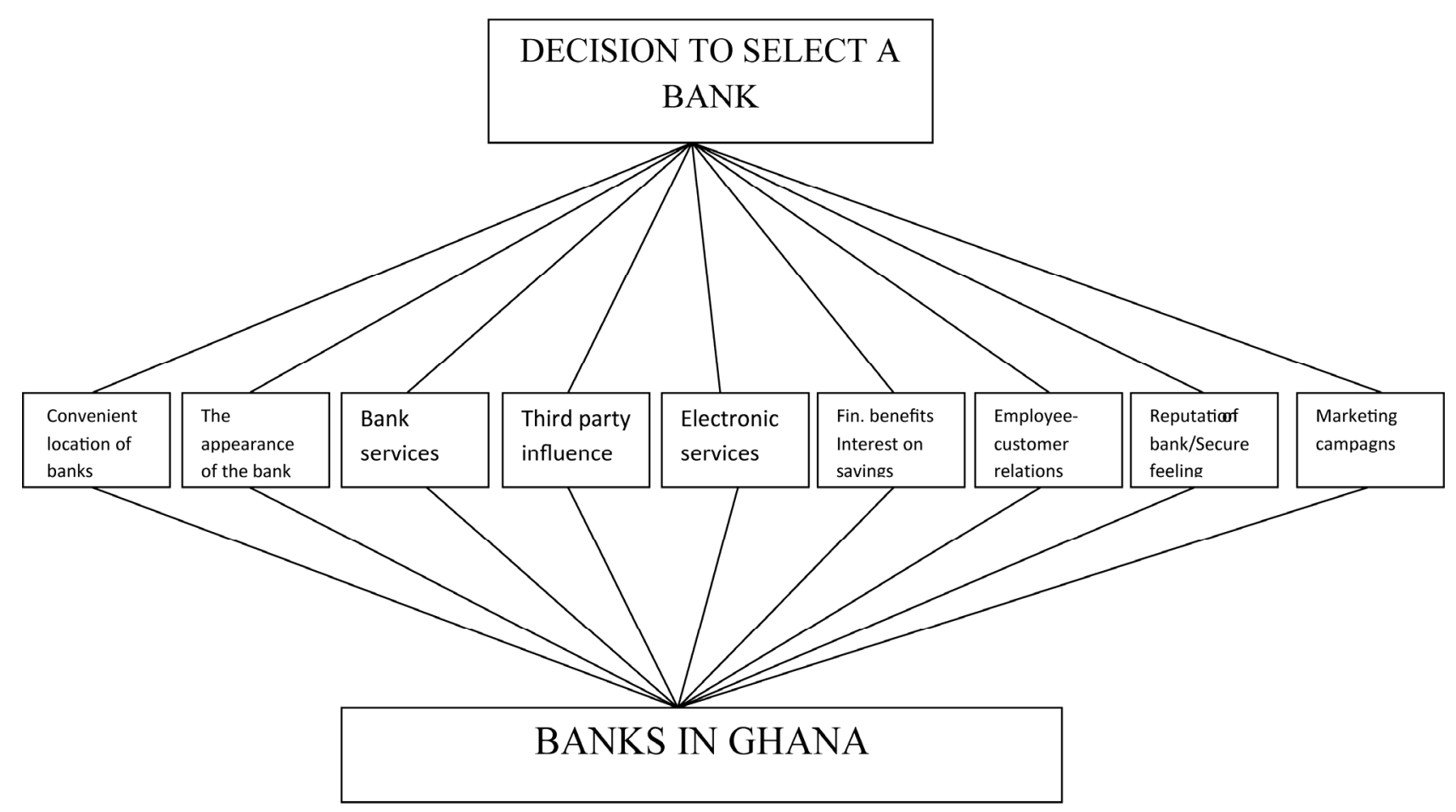

Figure 1. Decision hierarchy for bank selection; adapted from Ta and Har (2000). 


\section{Efforts Made to Enhance the Performance of the Proposed Research Approach}

Questions were asked in an interactive group setting where participants were free to talk with other group members. The discussion was loosely structured, and the moderator encouraged the free flow of viewpoints on the main theme for discussion. Having key themes and subquestions in advance lies in giving the researcher a sense of order from which to draw questions from unplanned encounters. Corbetta explains semi-structured interviews as follows: "The order in which the various topics are dealt with and the wording of the questions are left to the interviewer's discretion" [31]. Within each topic, the interviewer is free to conduct the conversation as he thinks fit, to ask the questions he deems appropriate in the words he considers best, to give explanation and ask for clarification if the answer is not clear, to prompt the respondent to elucidate further if necessary, and to establish his own style of conversation.

Having chosen the type of interview, we try to get reliability of performance by systematically adopting a conversation conducted to obtain research-relevant data. The interviewer made significant effort to create good interview conditions. We are aware of the problematic situation associated with the following five main areas of research interviewing-asking the questions, listening to the replies, ensuring that the respondent answers in full, recording the answers, and (usually later) reporting back the overall findings. Consequently, significant efforts were made in reading the interview questions at "slow normal" speed and in a neutral tone, but with emphasis on certain words (e.g. bank selection criteria) to help the respondent understand the questions. The researchers were aware that replies should be interesting if the questions are good. And were aware that the interviewer should not get distracted if the respondent sounds boring the most monotonous replies can turn out to be full and revealing. When the respondents did not answer the questions asked, time was given for the respondents to answer. This is crucial because respondents are hearing the question for the first time. They may need time to think; the researchers kept silent to encourage them to do so. In cases where replies or answers to the questions asked were inconsistent with something said earlier, the researchers referred back to the previous answers and reminded the respondent what he or she said earlier. This is usually enough to get an explanation.

Thus case study method is adopted because we want to have an in-depth understanding of the criteria that undergraduate students on the University of Ghana campus employ in selecting a bank (see Figure 1). Population is the university of Ghana undergraduate students. We interviewed a total of twelve undergraduates. Consistent with Bodet and Chanavat, six males and six females to offer gender balance and we used structured interview schedules [32]. The use of the schedule is to prevent us from deviating from asking irrelevant questions. The purposive sampling method was used to select the respondents. We spent 15 to 20 minutes on each student and recorded the interview with a Sony IC Recorder. We also took down notes to support the recorder in case of technology failure. Our study investigates ten criteria used in bank selection which includes: 1) Convenience; 2) Bank appearance; 3) Bank services; 4) Third party influences; 5) Electronic services; 6) Financial benefit; 7) Employee customer relations; 8) Secure feeling; 9) Marketing communication; 10) Reputation of bank.

\section{Presentation and Discussion of Findings}

The findings and discussions are presented concurrently in accordance with the criteria used in bank selections gleaned from the literature review. The presentation focuses on the individual criteria for selection to ascertain the dominants selection criteria and the less dominants ones. Ranking of bank selection criteria could be seen in Table 1.

\subsection{Selection Criteria 1-Convenience}

From the interview we conducted, convenience is considered by almost all the respondents to be very influential in their choice of selecting a bank. Convenience has been interpreted differently by our respondents as follows: "...of course, as in their customer service, how fast I can access them, that is how close they are to me". Other respondents stated; "I do consider that a lot"; "It will influence a lot in terms of everything, in terms of how fast their services are tailored to suit you; If banking with a certain bank and ATM is not always working you might keep the account but will bank elsewhere”; “... that one will influence me, Ghana commercial bank for example, I am with them because of the ease to get them". Another respondent joyously responded that convenience is: "very necessary, for instance, I could get them when am in school, at home, it makes banking enjoyable". Some of the respondents also consider the multiplicity of banks and their branches to mean convenience. For example: “....when there is easy access to the bank and its branches". Convenience as a selection attribute has been defined variously by the respondents. For some it means fast delivery of service, a reliable ATMs and even facilities such as dispensing water, urinary etc. “...but when I enter a bank, there should be facilities such as water, and place of convenience you should not feel any inconvenience in a banking hall”.

\subsection{Selection Criteria 2-Bank Appearance}

The appearance of a bank has very little effect among the criteria that influence the choice of a bank among the 
Table 1. Ranking of bank selection criteria.

\begin{tabular}{cc}
\hline The most important criteria in order of significance & The most unimportant criteria in order of significance \\
\hline 1. Convenience & 1. Secured feeling \\
2. Employee customer relations & 2. Bank appearance \\
3. Banking services/Financial benefits & 3. External influences \\
4. Reputation of the Bank & 4. Reputation of the Bank \\
5. Marketing communication/Bank appearance/Secured feeling. & 5. Marketing communication
\end{tabular}

respondents. The respondents interviewed recognize the importance of impressive edifices, but state that it will not really be a factor which will influence them. Some even think that the structures inspire confidence and show seriousness. The responses of some students are:

“...the appearance does not influence me...that the building should influence me, well not necessarily, if I will grade them, that is the last thing I will consider"; It might influence me personally, banks normally if you enter a bank and architecture is not nice it does really attract you because when you are entering and its looking nice you also feel good”; “...If its selection then I don't think so, but appearance will give you a level of confidence to enter but if its kind of dull then I will they will not have enough money to give me"; "YES! It will affect me, I will go for the attractive, because I will know the people are serious";

"For me things like that, those things don't add up"; "Structures should be presentable and will influence me a little; the surrounding and painting you will think they are '419' people who want to dupe me and take my money”; “No I won't consider appearance, don't mind the body but what goes inside, the bigger the building the more the rates".

\subsection{Selection Criteria 3-Bank Services}

Most of the respondents think that the services provided by their bank should be tailored towards the student needs. Their requirements for a banks' service is very basic. This may be due to the fact that; they are not working and do not have huge sums of money to save or otherwise. Some of the responses include the following: “... but basically, I only need ATM and debit cards. But if I were a businessman, I will consider all kinds of services such as internet banking etc.”; “...the most important aspect of it especially the interest on my money”; “... yeah the services are very important, the banking institution is to offer services they will influence, it will play a part, if a bank does not offer services tailored to suit students I might not choose the bank”; “...that one will influence me, I wanted to quit but because of their convenience I stayed”; "Yes they will affect me I will look out for the services that apply to my needs, if a bank does not have a service that will not affect me I won't go there”; “...bank service I will consider, some banks waste time in carrying out services and some customer relations are not good”; “...it should be fast and reliable, they wasting your time and no queues”; “...if they will give me something in return, not necessarily I given them my money”.

\subsection{Selection Criteria 4-Third Party Influences}

With regards to whether or not respondents' bank selection would be influenced by a third party, some of the respondents say they will consider it, but a large number would not consider it. Some of the responses provided include: "o.k. apart from all the factors, my sister banked with them and was quite comfortable, third party influence me, its ahead of the building of the bank"; "...personally it will not influence me”; “...no I don’t think so”; "Per the person experience, it will say that, that bank is good and based on that advise I will make good judgments' and go there because the person has used it and has seen that they have good services"; "It depends on what the persons know about the bank, you know your money will be secured, but I will not really be influenced because I will also do my underground investigations”; "Personally it will influence me, for instance my sister banks at Ecobank and she told me to bank there, and I complied with her directive”.

\subsection{Selection Criteria 5-Electronic Services}

This criterion according to some of the respondents will be useful to them in the future and some even do not understand it. This shows that the undergraduate student require only basic services satisfactorily. Some responses include the following: "Well, I am not really familiar with it, I don't think it will influence me"; "Yes it will influence me, due to locations, I am able to use the internet services instead, example is Cal bank”; “That one will count a little, since I don't really know the details of banks, but it might influence me"; "It will save time since you will be so easy and internet service at home or in the office thus no need to go and queue"; "Yes I will look at that because it will save the time of going there and the cost of going there; "It will influence me"; "Yeah 
but basically I only need ATM and a debit card but if I were a business man I will consider all kinds of services such as internet banking”.

\subsection{Selection Criteria 6-Financial Benefit}

Financial considerations seem to motivate some of the respondents in choosing the bank they would like to patronize: "Most important aspect of it especially the interest on my money"; "With reference to unique bank ezwich services there is $15 \%$ interest on it thus I opened my e-zwich account with them"; "Yes it counts, I should know my money will benefit me too and not only they using it"; "I know the banks use my money for some business, so if they get something they should give me something too". Some of the respondents also think they will consider it: "May be when I grow up but now now, and when I start working and saving actually, but now no".

\subsection{Selection Criteria 7-Employee Customer Relations}

One of the decisive factors in the bank selection process by the undergraduates. On a rank of five, the employee customer relation come second and is considered very important by the respondents. The employee customer relation for some of the respondents means the ability to explain the banking procedure to them and guide them if they are wrong:

"When I went to the HFC bank for instance the recaptionist was good, she smiled at me this made me like going there to check on my account"; "Very important well it can make me change my mind, when I went to Ecobank if the relations was not good I would have changed my mind, its very influential";

"Yeah that is also another I will consider, if you are not a banker its obvious you will not know everything so if there are people who will guide you and explain thing to you why not it will be another plus over the others"; "Yeah the way they treat me is also another factor, it's very necessary because it will encourage you to relate with them easily because if you are not happy it will be difficult to interact with them"; "It will also count, sometimes you need something, the way they relate with me"; "It is a problem when its to the general public"; "Yes if the employees are friendly and customer relations are good, you will know that all information will be given and all problems sent there will be met”.

\subsection{Selection Criteria 8-Secure Feeling}

The security of money deposited in a bank for some of the respondents is not possible for the money to get lost and therefore this criterion would not be part of the se- lection criteria. In the same vein others would consider the security of their money. Responses from the respondents show that security issues are akin with the reputation of the bank: "I do not consider that because if you leave there your security is still not guaranteed"; "Yeah, yeah because I for one, from their reputation I know they can be trusted, I guess that's why I look at their reputation"; "Yeah it will influence that is why I won't save with just any bank because, the goodwill they have"; "Personally won't go out for just any bank but has proved overtime"; "It will influence me because during the 2008 elections, I realized that data bank was on connection with the N.P.P so they started recording negative balances, so I had to take my money out because N.P.P was out of power"; "Yes it is necessary you wouldn't want to lose your money it will not be necessary, because I know that its not possible the money will get missing in the bank"; "I have never really thought about that, so it wouldn’t influence me”.

\subsection{Selection Criteria 9-Marketing Communication}

The respondents acknowledge that the communications that a bank put out could have influence, but state however that these communications would not per se influence them. We are of the view that, it's probably because they are enlightened and can determine the differences between perceived quality and actual quality of the service delivered. Here are their responses: "Exactly! It will affect me"; Yes I am sure because for the GT bank you will be so caught up in their song and it can influence people but haven't influenced me per say but if want to open another account, I will go to GT bank"; "Well personally it won't affect me anyway, it wont count on my choice of bank, marketing people are very bad people so marketing strategies are just to sway you for banking I won't go there"; "It may influence me if information conveyed suit something I need”; “OK! It does not affect me, I don't look at think advertisement stands for competence, you can have a nice advert and not be competent or their services not up to standard"; "It's not a factor"; "Some are just camouflages, they don't really do what they say, they just want customers and if they start its not for long, so I won't consider it”.

\subsection{Selection Criteria 10 - Reputation of Bank}

Some of the respondents explain that they feel good to be associated with a reputable bank whiles others would not consider a prestigious bank. Some explain that a good reputation is likely to result in good service delivery: "I will consider a bank institution that has enjoyed goodwill overtime over one I barely know"; "Reputation won’t influence me. Yes its necessary in that you can tell if 
bank is suitable for you or not in keeping your money with them; it will give you an idea of service delivery whether good or bad"; "It won't be a factor, first class and their services may not be good"; "Yes it really counts, sometimes you feel good to mention that you bank with a particular bank”.

\section{Postscript/Aftermath of Service Post-Acquisition Phase and Implications}

From the presentation and the discussion we realize that what really determines the selection of a particular bank over another is how you feel after you access the services. The respondents reveal feelings of happiness, sadness, cheerfulness, joyfulness, anger, and deceit.

Happiness: Happiness is good feeling about something. This the respondents show clearly in our interaction with them. Banking for them should end up making you happy to want to return to the banking hall. Here are some responses from the respondents: “...because if you are not happy it will be difficult to interact with them, for instance,...it makes banking enjoyable”; “...sometimes you feel good to mention that you bank with a particular bank”; “...banks normally if you enter a bank and architecture is not nice it does really attract you because when you are entering and it's looking nice you also feel good”. A smile from the service provider made majority of the respondents happy and contributed to their decision to become a loyal customer of the bank. For example: "When I went to the HFC bank for instance the recaptionist was good, she smiled at me this made me like going there to check on my account”. Thus, banks should make some efforts to do things that bring delight to their clienteles and make them happy.

Sadness: Sadness is the exact opposite of happiness. A feeling of grief, sorrow, depression, wretchedness etc is sadness. The respondents would want to eschew any service by a bank that would make them gloomy or otherwise that do not satisfy their needs. Here are some voices:

“...marketing people are very bad people so marketing strategies are just to sway you for banking I won't go there”; “...if a bank does not offer services tailored to suit students I might not choose the bank”; “...I will look out for the services that apply to my needs, if a bank does not have a service that will not affect me I won't go there". Thus banks should try their best to eliminate services that would make their consumers especially the feel depressed to want to avoid them.

Anger: A feeling of annoyance, irritation, fury, rage etc is anger. The respondents would not want a situation that will make them furious over the services of a bank and would therefore avoid a contact with such a bank. Examples from the respondents: “...it should be fast and reliable, they wasting your time and no queues”; "Banking with a certain bank and ATM is always out of order, you might keep the account but will bank elsewhere"; "Some banks waste time in carrying out services and some customer relations are not good". The relationship between the consumers and the bank must be cordial. According to a respondent, “....if you are not happy it will be difficult to interact with them”. Banks must remove any process that will end up annoying their clientele especially the undergraduate students.

Deceit: A feeling of betrayal, fraudulence, falsity etc is deceit. The respondents posit they would not be caught in the web of sham and would do anything to shun such services. The communication gap must be narrow enough to what was promised to what is actually delivered. Some considered marketers as people trained to deceive and therefore would pass up any marketing communications. Some responses: ...marketing people are very bad people so marketing strategies are just to sway you for banking I won't go there”; “I don't look at think advertisement stands for competence, you can have a nice advert and not be competent or their services not up to standard”; “...some are just camouflages, they don't really do what they say, they just want customers and if they start it's not for long, so I won't consider it”. As far as possible the banks must demonstrate integrity and promise only what they can deliver.

\section{Conclusions}

The aim of this paper is to investigate bank selection criteria among undergraduate students and to explore how consistent the findings of this current study compare with extant studies. The results show consistency with previous works in Ghana and elsewhere [12,13,16]. Theoretical contribution of this study entails highlighting bank selection criteria for potential young customers in the Africa South of Sahara. Therefore, the findings of this study build on extant knowledge and can be used as a point of departure to build future study. From the perspective of the managerial implication, this study can help bank practitioners to identify the major factors that may determine bank selection decisions among young customers. Providing insights on phenomenon will help banks to identify the appropriate marketing strategies needed to attract new customers and retain existing ones. Findings from this study reveal that the convenience dominating is asserting the ease with which consumers want to access their services and also to save them enough time. "Time is the only commodity worth anything anymore. Consumers sacrifice money in order to save time. The convenience factor also explains the themes of being happy after a bank service. We can conclude that a bank that provides a convenient service (convenience in whatever form) that meets the needs of the consumers will have an 
edge over other competitors' that provides otherwise.

It is pertinent to mention that we investigated one type of young customers in this study, that is, the university students. Despite the fact that this market segment is vital to study, other segments of young customers, who may have different selection processes, should not be ignored. Furthermore, although the findings from this study can possibly be generalized to other African countries which share many common factors (for example: economy, culture, language, religion, standard of living, geography, and political system), it would be interesting to examine the applicability of the findings by replicating similar studies in other African countries.

\section{REFERENCES}

[1] G. M. Doan, K. Shirahada and M. Kosaka, "Service Mediator Model for Value Co-Creation Based on Service Dominant Logic,” Journal of Service Science and Management, Vol. 6, No. 1, 2013, pp. 11-19.

[2] B. Grady and H. Spencer, "Managing Commercial Banks," Prentice-Hall, Englewood Cliffs, 1990.

[3] M. Almossawi, "Bank Selection Criteria Employed by College Students in Bahrain: An Empirical Analysis,” International Journal of Bank Marketing, Vol. 19, No. 3, 2001, pp. 115-125.

[4] B. Narteh and N. Owusu-Frimpong, "An Analysis of Students' Knowledge and Choice Criteria in Retail Bank Selection in Sub-Saharan Africa: The Case of Ghana," International Journal of Bank Marketing, Vol. 29, No. 5, 2011, pp. 373-397. doi:10.1108/02652321111152909

[5] C. Lymperopoulos, I. A. Chaniotakis and M. Soureli, "The Importance of Service Quality in Bank Selection for Mortgage Loans,” Managing Service Quality, Vol. 16. No. 4, 2006, pp. 365-379. doi:10.1108/09604520610675702

[6] D. R. Andrews, J. M. Hood and U. Tate, "Selection of Commercial Bank CEOs in the Deregulated Environment: Influencing Factors,” American Journal of Business, Vol. 7, No 2, 1992, pp. 25-32. doi:10.1108/19355181199200013

[7] J. R. Nielsen and R. Trayler, "The Bank Selection Process and Market Definition in Australia," Journal of Financial Regulation and Compliance, Vol. 10, No. 1, 2002, pp. 2230. doi:10.1108/13581980210810094

[8] H. Amin, M. R. Abdul Hamid, S. Lada and R. Baba, “Cluster Analysis for Bank Customers' Selection of Islamic Mortgages in Eastern Malaysia: An Empirical Investigation," International Journal of Islamic and Middle Eastern Finance and Management, Vol. 2, No. 3, 2009, pp. 213-234. doi:10.1108/17538390910986344

[9] Y. Xu, X. Ye and F. Zhang, "The Customer Satisfaction Research of 7-ELEVEn Stores in Hong Kong,” Journal of Service Science and Management, Vol. 6, No. 1, 2013, pp. 46-55. doi:10.4236/jssm.2013.61006

[10] H. Yue and G. Tom, "How the Chinese Select Their Banks,” Journal of Retail Banking, Vol. XVI, No. 4, 1995.
[11] R. Hinson and B. Hammond, "Service Delivery in Ghana's Banking Sector,” In R. Hinson, Ed., African Marketing Practice: Cases from Ghana, Sedco Publishing Limited, Accra, 2006, pp. 43-63.

[12] N. Owusu-Frimpong, "Patronage Behavior of Ghanaian Bank Customers,” International Journal of Bank Marketing, Vol. 17, No. 7, 1999, pp. 335-341. doi:10.1108/02652329910305698

[13] R. Hinson, N. Owusu-Frimpong and J. Dasah, "Key Motivations for Bank Patronage in Ghana,” International Journal of Bank Marketing, Vol. 27, No. 5, 2009, pp. 381-399. doi:10.1108/02652320910979898

[14] B. R. Lewis, "Service Quality: An International Companion of bank Customers' Expectations and Reception," Journal of Marketing Management, Vol. 7, 1991, pp. 4762. doi:10.1080/0267257X.1991.9964139

[15] M. Zineldin, "Bank Strategic Positioning and Some Determinants of Bank Selection,” International Journal of Bank Marketing, Vol. 14, No. 6, 1996, pp. 12-22. doi:10.1108/02652329610130136

[16] C. Blankson, J. Ming-Sung Chang and N. Spears, "Determinants of Banks Selection in USA, Taiwan and Ghana," International Journal of Bank Marketing, Vol. 25, No. 7, 2007, pp. 469-489. doi:10.1108/02652320710832621

[17] M. W. Pass, "Western US College Students: Banking Preferences and Marketplace Performance," Journal of Financial Services Marketing, Vol. 11, 2006, pp. 49-63. doi:10.1057/palgrave.fsm.4760016

[18] P. Gerrard and J. B. Cunningham, "Singapore's Undergraduates: How They Choose Which Bank to Patronize," International Journal of Bank Marketing, Vol. 19, No. 3, 2001, pp. 104-114. doi:10.1108/02652320110388531

[19] H. P. Ta and K. H. Har, "A Study of Bank Selection Decisions in Singapore Using the Analytical Hierarchy Process,” The International Journal of Bank Marketing, Vol. 18, No. 4, 2000, pp. 170-180. doi:10.1108/02652320010349058

[20] D. Thwaites and L. Vere, "Bank Selection Criteria-A Student Perspective,” Journal of Marketing Management, No. 11, 1995, pp. 133-149. doi:10.1080/0267257X.1995.9964334

[21] J. Schram, "How Students Choose Their Banks," US Banker, Vol. 110, 1991, pp. 75-78.

[22] B. R. Lewis, "Student Accounts-A Profitable Segment?" European Journal of Marketing, Vol. 16, No. 3, 1982, pp. 63-72. doi:10.1108/EUM0000000004839

[23] A. D. Gray, "Student Attitudes towards Banking," Unpublished BSc Dissertation, University of Strathclyde, Scotland, 1977.

[24] S. Mokhlis, "Determinants of Choice Criteria in Malaysia's Retail Baking: Analysis of Undergraduate Students in Malaysia," European Journal of Economics, Finance and Administrative Sciences, No. 16, 2009.

[25] Lee and J. Marlowe, "How Consumers Choose a Financial Institution: Decision-Making Criteria and Heuristics," International Journal of Bank Marketing, Vol. 21, No. 2, 2003, pp. 53-71. doi:10.1108/02652320310461447 
[26] C. T. Tan and C. Chua, "Intentions, Attitude and Social Influence in Bank Selection: A Study in an Oriental Culture,” International Journal of Bank Marketing, Vol. 4, No. 3, 1986, pp. 43-53. doi:10.1108/eb010783

[27] T. Hun Phuong and H. Kar Yin, “A Study of Bank Slection Decisions in Singapore Using the Analytical Hierarchy Process," International Journal of Bank Marketing, Vol. 18, No. 4, 2000, pp. 170-180. doi:10.1108/02652320010349058

[28] W. T. Anderson, E. P. Fox and D. G. Fulcher, "Bank Selection Decision and Market Segmentation,” Journal of Marketing, Vol. 40, 1976, pp. 40-45. doi:10.2307/1250674
[29] O. E. Omar, “Gender-Based Retail Bank Choice Decision in Nigeria,” Journal of Retail Marketing Management Research, Vol. 1, No. 1, 2007, pp. 20-21.

[30] R. K. Yin, “Case Study Research: Design and Methods,” 3rd Edition, Sage Publications, Thousand Oaks, 2003.

[31] P. Corbetta, "Social Research Theory, Methods and Techniques,” Sage Publications, London, 2003

[32] G. Bodet and N. Chanavat, "Building Global Football Brand Equity-Lessons from the Chinese Market," Asia Pacific Journal of Marketing and Logistics, Vol. 22, No. 1, 2010, pp. 55-66. doi:10.1108/13555851011013155 